\section{The Effects of Voting Ownership Concentration on Social and Environmental Disclosure: Empirical Evidence from Brazil}

\author{
Dante Baiardo Cavalcante Viana Junior ${ }^{1}$ \\ ${ }^{1}$ University Institute of Lisbon, Business Research Unit, Lisboa, Portugal \\ Vicente Lima Crisóstomo ${ }^{2}$ \\ ${ }^{2}$ Federal University of Ceará, Accounting Department, Fortaleza, Brazil
}

Received on

$12 / 20 / 2017$

Approved on

02/06/2019

\section{Responsible editor:}

Prof. Dr. João Mauricio Gama

Boaventura

\section{Evaluation process:}

Double Blind Review

\begin{abstract}
Purpose - This study aims to analyze the effects of voting ownership concentration on the social and environmental disclosure of Brazilian companies in their Annual Financial Statements.

Design/methodology/approach - Econometric models were estimated considering a sample of 1,252 annual observations of 252 companies in the period 2010-2014, and the social and environmental disclosure was measured through a lexical analysis performed by counting 75 words and key expressions related to social and environmental practices.

Findings - Our findings suggest that the social and environmental disclosure of Brazilian companies is positively correlated with their voting ownership concentration. In addition, if the company is listed in the Corporate Sustainability Index or if it is in a potentially aggressive industry with respect to the environment, this also positively contributes to a higher degree of social and environmental disclosure.
\end{abstract}

Originality/value - Our study contributes to the literature on social and environmental disclosure and its association with ownership structure by providing evidence in an emerging market characterized by a high concentration of control.

Keywords - Social and Environmental Disclosure, Voting Ownership Concentration, Determinants.

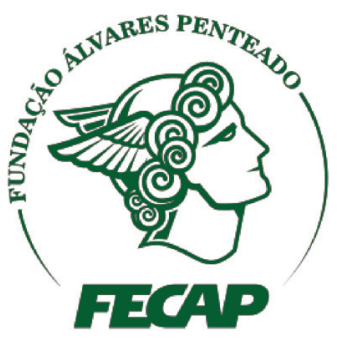

Review of Business Management

DOI: $10.7819 /$ rbgn.v21i5.4026 


\section{Introduction}

Climate change, international environmental conferences, and environmental accidents have been important factors for the increase in stakeholders' demands for firms' social and environmental disclosure (Fernandes, 2013). This stakeholder pressure may be a factor that has contributed to the adoption of corporate social responsibility practices, which may have an effect on a firm's competitive capacity and even in its search for legitimacy, leading to the increasing dissemination of information about social and environmental responsibility (Fernandes, 2013; Barth, Cahan, Chen, \& Venter, 2016; Viana Junior \& Crisóstomo, 2016).

Many benefits are expected by firms due to the adoption of social and environmental disclosure practices, such as a reduction in cost of capital (Gamerschlag, Moller, \& Verbeeten, 2011), an improvement in corporate reputation (Cardoso, De Luca, \& Gallon, 2014), and a reduction in market value uncertainty (Dhaliwal, Li, Tsang, \& Yang, 2011). In this discussion, Marquezan, Seibert, Bartz, Barbosa, and Alves (2015) emphasize that in Brazil, despite the changes in accounting legislation promoted by Law No. 11,638/2007, the changes did not go so far as to make social and environmental disclosure mandatory, which means this activity is voluntary on the part of firms.

Some theories, as is the case of the Stakeholder Theory, try to explain social and environmental disclosure (Freeman \& Phillips, 2002). The Stakeholder Theory proposes that the disclosure of information on social responsibility may be due to the pressures from the various firm stakeholders. The Legitimacy Theory suggests that voluntary disclosure practices are motivated by the pursuit of legitimacy by the firm (Suchman, 1995). In light of these theories, research has sought the determinants of social and environmental disclosure. These factors may be related to the firm's economic-financial characteristics (Marquezan et al., 2015; Kansal,
Joshi, \& Batra, 2014; Zhang, 2015; Michelon, 2011; Abdullah, Percy, \& Stewart, 2015), or even linked to the legal and institutional environment in which organizations operate (Delmas, Hoffmann, \& Kuss, 2011; Rover \& Santos, 2014). Under the Agency theoretical framework, it is important to seek mechanisms that favor the reduction of conflicts among stakeholders, and disclosure of firm information is one such mechanism for reducing these conflicts. High levels of ownership concentration contribute to minimizing conflicts between shareholders and managers due to the better alignment of interests between the parties, among other factors. However, high ownership concentration can also favor the emergence of conflicts between controlling and minority shareholders.

Ownership concentration has been shown to be able to interfere with firm policies, including social and environmental policy (Crisóstomo, \& Freire, 2015; Okimura, Silveira, \& Rocha, 2007). In this context, the disclosure of firm social and environmental information helps the process of firm legitimacy with external stakeholders. In this framework, controlling shareholders, usually with a longer-term perspective to remain in the firm's ownership, may be more interested in the search for legitimacy than minority shareholders, and this may lead to a greater volume of social and environmental disclosure (Barnea \& Rubin, 2010; Crisóstomo \& Freire, 2015; Faller \& Knyphausen, 2016; Li \& Zhang, 2010).

The search for legitimacy of firm actions, and the concern with firm image and reputation, may encourage investments in social and environmental responsibility with the respective intensification of its disclosure (Bebbington, Larrinaga-González, \& Moneva-Abadía, 2008; Brown, Guidry, Patten, 2009). In this context, studies still point to an association between these concerns and aspects of ownership structure (Barnes \& Rubin, 2010; Crisóstomo \& Freire, 2015; Rees \& Rodionova, 2015).

Considering the relevance of the firm's social and environmental policy and its respective 
disclosure, and the reality of excess power in the hands of controlling shareholders arising from a high ownership concentration, which favors the prevalence of their interests, as is the case in Brazil, this study tries to answer the following research question: What is the influence of ownership concentration on firms' social and environmental disclosure? Thus, the objective of this study is to investigate the influence of the voting ownership concentration on the social and environmental disclosure of the Brazilian firms listed in the B3 exchange in the period 2010-2014.

Through lexical analysis of firms' annual financial statements and performing correlation analysis and estimating a set of econometric models for a sample of 1,252 annual observations of 252 firms, our results indicate that there is a positive effect of the voting ownership concentration on the social and environmental disclosure. These results reinforce arguments from previous research that indicate that controlling shareholders seem to be concerned about disclosing social and environmental information to the market. Controlling shareholders may be finding motivation in the search for legitimacy and an improvement in the firm's reputation and image (Diez, Gago, \& Garcia, 2012; Huafang, \& Jianguo, 2007). In addition, our findings indicate that firm disclosure of social and environmental information is also explained by firm profitability, by whether the firm is a member of the ISE index, and whether the firm belongs to a potentially environmentally aggressive industry.

This study contributes to the literature by using a social and environmental disclosure index based on a lexical analysis of mandatory accounting reports over a long period of five years, increasing the knowledge regarding factors that contribute to social and environmental disclosure in Brazil. Knowing about the level of social and environmental disclosure and firm attributes that determine this type of disclosure is important to academics and market practitioners. Researchers and market professionals will have additional evidence on the effects of ownership concentration on the level of firm social and environmental disclosure, which has a connection with Agency Theory. In addition, the fact that social and environmental disclosure is more intense for firms included in the ISE sustainability index and for firms from potentially environmentally aggressive industries indicates that such firms are motivated to increase their disclosure level, which is associated with Legitimacy Theory, as well as being related to Voluntary Disclosure Theory.

Ownership concentration has been shown in the literature to be able to interfere in several firm policies, including social and environmental policy (Crisóstomo \& Freire, 2015; Okimura, Silveira, \& Rocha, 2007). This association may be caused by agency conflicts. In the case of social and environmental policy, controlling shareholders' interests may prevail over the interests of other stakeholders. That is one motivation for this work, together with the evaluation of factors that are suggested as also being able to interfere in the level of social and environmental disclosure, as is the case of a presence in sustainability indices and whether the firm is from an environmentally risky industry.

This study differs from previous research in some respects. Firstly, it does so by using lexical analysis to operate the disclosure of information about social and environmental activities, a method still little explored in Brazil. The application of several techniques of content analysis in studies on the subject of social and environmental disclosure has been questioned in the literature (Abhayawansa, \& Guthrie, 2012; Gamerschlag et al., 2011), among other reasons due to the researcher's subjectiveness when judging certain aspects of what is to be quantified. Thus, the use of lexical analysis to measure disclosure helps to mitigate this deficiency. It is also worth mentioning the period of analysis (2010-2014), which provides an additional contribution in relation to other works in Brazil that have worked with shorter periods of time (Domenico et al., 2015; Dhaliwal et al., 2011; Marquezan et al., 2015; Rover, \& Santos, 2014; Rover, Tomazzia, 
Murcia, \& Borba, 2012; Batista, Cruz, \& Bruni, 2016). Finally, the paper presents possible firm attributes that are still scarcely considered in the literature as possible determinants of voluntary social and environmental disclosure, such as the ownership concentration, firm membership of the sustainability index, and whether the firm is from an environmentally risky industry.

\section{Social and Environmental Disclosure and Ownership Concentration}

Agency Theory intends to explain the conflicts between firm owners (principal) and firm managers (agent) resulting from the separation between firm ownership and firm control, which makes the firm a set of contracts (Fama \& Jensen, 1983). The contract between the shareholders (principal) and firm managers (agent) is considered as the central point, the unit of analysis, in the agency context (Eisenhardt, 1989). In this context, it is necessary to find ways to minimize such conflicts in order to reduce the agency costs resulting from them (Jensen \& Meckling, 1976). A high ownership concentration is seen as a relevant factor that contributes to the alignment of interests between ownership and management due to the power exercised by controlling shareholders over firm management, which leads to the reduction of conflicts between principal and agent (Hitt, Ireland, \& Hoskisson, 2008). On the other hand, ownership concentration may also be detrimental due to the possibility of controlling shareholders' interests prevailing over those of minority shareholders, giving rise to the principal-principal agency model, in which the main conflict is between controlling shareholders and minority shareholders (Morck, Wolfenzon, \& Yeung, 2005; Okimura, Silveira, \& Rocha, 2007; Renders \& Gaeremynck, 2012). In fact, conflicts of interest between majority and minority shareholders have been pointed out as more relevant in markets characterized by a high ownership concentration, as is the case in emerging markets (Brandão, \&
Crisóstomo, 2015; Lin \& Chuang, 2011; Young, Peng, Ahlstrom, Bruton, \& Jiang, 2008).

The origin of the country's legal system is considered one of the factors that matter for agency conflicts, due, for example, to the divergences in legislation with respect to external investor protection (La Porta, Lopez-de-Silanes, Shleifer, \& Vishny, 2000). Therefore, taking into account the agency problems in Brazil regarding ownership concentration as a critical sign of conflicts between majority and minority shareholders, it can be assumed that minority shareholders would be concerned about ownership structure, given the low legal enforcement regarding the protection of external investors (Djankov, La Porta, Lopez-deSilanes, \& Shleifer, 2008; La Porta et al., 2000; Shleifer \& Wolfenzon, 2002).

There is a consensus regarding the need to reduce informational asymmetry between firms and external investors, which is considered a way to strengthen markets. Such a reduction has been tried through legal instruments and the action of market institutions (Frankel \& Li, 2004). Informational asymmetry between majority and minority shareholders is also relevant, as reducing it can minimize conflicts between them (Cullinan, Wang, Wang, \& Zhang, 2012). The disclosure of periodic accounting reports containing financial information is the traditional instrument that allows for a reduction in informational asymmetry, either between the firm and the market, or between controlling and minority shareholders. Information on the firm's social and sustainability policy is being incorporated into the traditional statements as a means of showing the firm's concern about these issues, minimizing informational asymmetry and aiming to legitimize activities and improve reputation (Brammer \& Pavelin, 2004; Carroll \& Shabana, 2010).

Accounting information disclosure is therefore an instrument that helps in mitigating agency conflicts between the firm and market, as well as between controlling and minority shareholders (Guedhami \& Pittman, 2006). Thus, in order to resolve these conflicts, voluntary disclosure, including on social and environmental 
actions, may moderate the private benefits of control by controlling shareholders, since more disclosure contributes to greater accountability of management and controlling shareholders (Ball, Kothari, \& Robin, 2000).

Previous studies have found evidence on the influence of aspects of ownership structure over the level of firm disclosure, due to different reasons associated with shareholders' interests (Barako et al., 2006; Eng, \& Mark, 2003; Huafang \& Jianguo, 2007; Razak \& Mustapha, 2013). In this context, there might be concern about firm reputation and image, which may be associated with the interests of controlling shareholders, whose personal image is linked to the firm. In this way, the practice of disclosing Corporate Social Responsibility (CSR) can be influenced by the goal of achieving a better reputation (Bebbington, Larrinaga-González, \& Moneva-Abadía, 2008; Brammer \& Pavelin, 2004; Deephouse \& Carter, 2005).

The issue of social and environmental disclosure has motivated the development of research in different aspects. Some researchers have sought to evaluate the degree of content in CSR reports, with the results indicating little depth and comprehensiveness of the content reported by firms regarding their social and environmental actions (Bouten, Everaert, Van Liedekerke, De Moor, \& Christiaens, 2011; Epstein, 2003). Another set of studies has sought the explanatory factors of social and environmental disclosure using different theories, with the results indicating that, in fact, there are firm attributes, as well as exogenous factors, that interfere in firm social and environmental disclosure (Costa \& Crisóstomo, 2017; Naser, Al-Hussaini, Al-Kwari, \& Nuseibeh, 2006; Wang, Song, \& Yao, 2013). The literature has pointed to ownership structure as a relevant factor for the degree of content reported in sustainability reports under the argument that agency conflicts associated with shareholders' interests may interfere with the firm's CSR policy and disclosure (Ghazali, 2007; Eng \& Mak, 2003).
Controlling shareholders tend to have a long-term interest in the firm compared to minority shareholders, who can easily direct their investments to other firms. The long-term objectives would be related to a concern about improving firm image and prestige, which in turn would be related to firm reputation and legitimacy of activities (Bebbington, LarrinagaGonzález, \& Moneva-Abadía, 2008; Crisóstomo $\&$ Freire, 2015). These concerns are aligned with the expected potential of CSR for firm value creation, which also involves a medium- and long-term perspective that may conflict with short-term return interests on the part of minority shareholders. When conflicts of interests are present, controlling shareholders may use their power in order to prioritize their objectives even if they conflict with those of minority shareholders. This fact could stimulate controlling shareholders to present themselves in the market as "socially and environmentally appropriate," in search of legitimacy and reputation, thus enhancing social and environmental disclosure practices as a way of publicizing such actions, in the search to gain prestige and image, as suggested by the following hypothesis:

\section{H: The level of social and environmental disclosure of Brazilian firms is positively influenced by the voting ownership concentration.}

\section{I Other Explanatory Factors of Social and Environmental Disclosure}

There are also other determinants of firm social and environmental disclosure. A high degree of possible social and environmental damage due to firm activities raises the demand from stakeholders for more responsible firm behavior in preventing environmental damage. This higher stakeholder concern pressures firms to adopt effective instruments to ensure social and environmental responsibility, which leads to higher levels of disclosure by firms from environmentally 
risky industries (Wilmshurst \& Frost, 2000). In fact, findings from studies in different markets have signaled that firms from industries considered to be more aggressive toward the environment implement proactive environmental strategies to comply with environmental norms and communicate them, as well as their results, which increases the degree of disclosure (Albertini, 2013; Legendre \& Coderre, 2013). Results have been documented in Malaysia (Said, Zainuddin \& Haron, 2009), the United Kingdom (Gray, Javad, Power, \& Sinclair, 2001), Germany (Delmas et al. \& Wateringen, 2001), and Canada (Bewle \& $\mathrm{Li}, 2000)$. This argument and the international evidence motivate further assessment of this issue in Brazil.

In the Brazilian case, it is appropriate to comment on the Brazilian Environmental Policy, originally established by Law No. 6,938/1981, and amended by Law No. 10,165/2000, which establishes the Environmental Control and Inspection Fee (ECIF), classifying the activities of certain economic industries as low, medium, and high environmental impact. In general terms, firms considered to be more environmentally aggressive toward the environment will have a higher ECIF. Thus, empirical results presented by the literature indicate that firms classified as potentially aggressive toward the natural environment would have a greater motivation to undertake social and environmental actions (Delmas et al., 2011), including incurring more expenses with activities of this nature (Crisóstomo, Souza, \& Parente, 2012), which could increase their levels of social and environmental disclosure (Rover \& Santos, 2014; Viana Junior \& Crisóstomo, 2016). This set of factors gives rise to the expectation that firms from industries that are potentially more aggressive toward the environment have a higher degree of social and environmental disclosure.

Under a different framework, following the trend to create instruments that signal firms' efforts in developing sustainability activities, there is the development of market sustainability indices, as in the case of the Dow Jones
Sustainability Index - DJSI; and the FTSE4Good. In Brazil, the B3 Corporate Sustainability Index (ISE) was launched in 2005. The ISE aims, among other purposes, to promote social and environmental policies among firms (Rufino, Mazer, Machado, \& Cavalcante, 2014). In terms of ISE membership, it is proposed that firms that are ISE members show higher degrees of social and environmental disclosure compared to nonISE firms, given that ISE firms must show better levels of commitment to sustainability, based on the tough competition faced by firms that want to form part of the ISE portfolio. In the selection process, firms are required to show that they are indeed committed to social and environmental actions (Rover \& Santos, 2014). Findings in this direction have been documented in Brazil, signaling that firms composing the ISE portfolio seem to be committed to social responsibility and environmental sustainability (Silva, 2016). This line of reasoning motivates the expectation that the degree of social and environmental disclosure of Brazilian firms is influenced by ISE membership.

The literature has suggested and documented evidence signaling that firm profitability and firm size have a positive influence on the level of social and environmental disclosure. Regarding profitability, the Stakeholder Theory proposes the existence of a virtuous cycle between CSR and firm performance on the grounds that social and environmental concern may help firm value creation by allowing gains in image and reputation due to a positive sensitivity of society with relation to the firm (Freeman, \& Phillips, 2002). Additionally to this proposition, there is the fact that more profitable firms tend to have more funds available to undertake CSR actions, as proposed by the slack resources hypothesis (Baron, Harjoto, \& Jo, 2009; Griffin \& Mahon, 1997). This approach, coupled with previous results in different markets that signal a positive influence of profitability on firm social and environmental disclosure (Marquezan et al., 2015; Kansal et al., 2014; Zhang, 2015; Michelon, 
2011), strengthens the argument that profitability has a positive effect on the level of social and environmental disclosure of Brazilian firms.

\section{Research Design}

\section{I Sample}

This study is based on a sample of 252 firms listed in the Brasil, Bolsa, Balcão - B3 exchange, from 10 different economic industries, according to the classification proposed by Economática, also observing the NAICS (North American Industry Classification System) classification. The period of analysis was from 2010 to 2014 , involving a total of 1,252 observations. Table 1 shows the distribution of the observations over the analysis period (2010-2014) by economic industries.

Table 1

Sample division by economic industry

\begin{tabular}{|c|c|c|c|c|c|c|c|}
\hline Industries & 2010 & 2011 & 2012 & 2013 & 2014 & TOTAL & $\%$ \\
\hline Construction and Transportation & 28 & 28 & 28 & 28 & 28 & 140 & 11.18 \\
\hline Administrative services & 20 & 20 & 21 & 20 & 19 & 100 & 7.99 \\
\hline Energy, Gas, and Water & 42 & 43 & 43 & 43 & 42 & 213 & 17.01 \\
\hline Financial & 26 & 26 & 25 & 26 & 25 & 128 & 10.22 \\
\hline Tobacco and Beverage & 10 & 10 & 10 & 10 & 10 & 50 & 3.99 \\
\hline Mining and Chemicals & 24 & 24 & 24 & 24 & 24 & 120 & 9.58 \\
\hline Oil and Gas & 15 & 15 & 15 & 15 & 15 & 75 & 5.99 \\
\hline Textiles, Clothing, and Footwear & 22 & 22 & 22 & 22 & 22 & 110 & 8.79 \\
\hline Pulp and paper & 7 & 7 & 7 & 7 & 7 & 35 & 2.80 \\
\hline Others & 56 & 57 & 56 & 56 & 56 & 281 & 22.44 \\
\hline TOTAL & 250 & 252 & 251 & 251 & 248 & 1,252 & 100 \\
\hline
\end{tabular}

Table 2 shows the sample stratification by the degree of industry environmental impact, as established by the current Brazilian Environmental Policy through Law No. 10,165/2000. For each firm in the sample, it was verified whether its industry was listed in Law No. 10,165/2000 as Low, Medium, or High Environmental Impact.
Firms from industries not listed in Law No. $10,165 / 2000$ were classified as "Industries not listed in Law No. 10,165/2000," and this group consists of firms from industries considered to present the least potential to cause environmental damage.

Table 2

Division of the sample by industries according to the level of environmental impact according to Law No. 10,165/2000

\begin{tabular}{lccccccc}
\hline ENVIRONMENTAL IMPACT & $\mathbf{2 0 1 0}$ & $\mathbf{2 0 1 1}$ & $\mathbf{2 0 1 2}$ & $\mathbf{2 0 1 3}$ & $\mathbf{2 0 1 4}$ & TOTAL & \% \\
\hline Industries not listed in Law No. 10,165/2000 & 115 & 116 & 115 & 115 & 113 & $\mathbf{5 7 4}$ & $\mathbf{4 5 . 8 5}$ \\
Low Impact Industry & 2 & 2 & 2 & 2 & 2 & $\mathbf{1 0}$ & $\mathbf{0 . 8 0}$ \\
Medium Impact Industry & 99 & 100 & 100 & 100 & 99 & 498 & 39.78 \\
High Impact Industry & 34 & 34 & 34 & 34 & 34 & $\mathbf{1 7 0}$ & $\mathbf{1 3 . 5 8}$ \\
\hline TOTAL & $\mathbf{2 5 0}$ & $\mathbf{2 5 2}$ & $\mathbf{2 5 1}$ & $\mathbf{2 5 1}$ & $\mathbf{2 4 8}$ & $\mathbf{1 , 2 5 2}$ & $\mathbf{1 0 0}$ \\
\hline
\end{tabular}




\subsection{Variables and Model}

Each firm's social and environmental disclosure index was measured through lexical analysis, based on the data search and counting the presence of 75 key words and expressions related to social and environmental disclosure in the firms' Annual Financial Statements (AFS) - a mandatory disclosure document for firms registered at the Brazilian Securities and Exchange Commission, pursuant to CVM Instruction 358/02, 480/09, and 481/09. These statements comprise management reports, financial statements, explanatory notes, board statements, and audit opinions, among others topics. In this sense, it should be noted that the lexical analysis based on the Annual Financial Statements considers the value relevance of the mandatory statements from the perspective of the market agents (Al Jifri \& Citron, 2009; Hand, 2005; Madeira \& Costa Junior, 2015). In addition, the social and environmental information contained in these reports, a priori, is not mandatory, so that the firm discloses such information because it sees it as relevant. Thus, the study advances the research by focusing its attention on Annual Financial Statements, which is different from previous research focused on sustainability reports (Domenico et al., 2015; Marquezan et al., 2015; Silva et al., 2015; Tannuri \& Van Bellen, 2014).

Alotaibi (2016) argues that one of the most relevant decisions that needs to be made during lexical analysis is the definition of units of analysis, given that several units of measure might be used, such as the document count of words, phrases, lines, pages, page proportion, or even a combination of these, which tries to compensate for the limitations and benefits of each method. Gamerschlag et al. (2011) explain that the operationalization of disclosure through the search for specific terms softens the subjectiveness present in several studies that use content analysis, given that, in these studies, the researcher is responsible for making a judgment on certain aspects of what is sought to be quantified, such as if a certain expression related to disclosure should be classified as positive or negative (Viana Junior, \& Crisóstomo, 2016). Abhayawansa and Guthrie (2012), Gamerschlag et al. (2011), and Huang, Zang, and Zheng (2014) also comment that this type of methodology provides concrete results in corporate reporting research, allowing the researcher to evaluate the extent of disclosure of various items - especially because in many situations the social and environmental information is mainly provided qualitatively.

Key words and phrases were chosen based on the Global Reporting Initiative (GRI) disclosure guidelines, given the relevance that GRI has achieved and its recognized expertise (Marquezan et al., 2015; Legendre \& Coderre, 2013). Table 3 exhibits the words and expressions searched for in the Annual Financial Statements of the firms related to social and environmental disclosure. The search and quantification of words and expressions was done with the aid of the FineCount software, which is for professional use for tabulation and stratification of several factors in content analysis (characters, spaces, words, lines, pages, repetitions, etc.). 
Table 3

Key words and expressions used to calculate the social and environmental disclosure index

\begin{tabular}{|c|c|c|c|c|}
\hline Absenteeism & Spills & Alternative Energy & Toxic Waste & Residue \\
\hline Environmental Audit & $\begin{array}{c}\text { Professional } \\
\text { Development }\end{array}$ & Sustainable Energy & Environment & Product Liability \\
\hline Biodiversity & $\begin{array}{c}\text { Sustainable } \\
\text { Development }\end{array}$ & Fauna & Environmental & Reuse \\
\hline Health Campaign & Human Rights & Flora & Equal Opportunities & Reuse \\
\hline Internal Communication & Ecology & Forest & Ozone & Environmental Risk \\
\hline Community & Ecological & Hunger & Environmental Liability & Customer Health \\
\hline Collective Agreement & Education & $\begin{array}{c}\text { Environmental } \\
\text { Management }\end{array}$ & Plan for Jobs & Occupational Health \\
\hline $\begin{array}{l}\text { Environmental } \\
\text { Conservation }\end{array}$ & $\begin{array}{c}\text { Environmental } \\
\text { Education }\end{array}$ & $\begin{array}{c}\text { Environmental } \\
\text { Impact }\end{array}$ & Public Policies & Job Satisfaction \\
\hline Corruption & Greenhouse Effect & Salary Incentive & Social Project & Customer Security \\
\hline Child Care & Effluent & ISO 14001 & Pollution & Social and Environmental \\
\hline Carbon Credit & Gas Emission & ISO 26000 & Recycling & Sustainability \\
\hline $\mathrm{CO} 2$ & Toxic Emission & Know-how & Human Resources & Forced Labor \\
\hline Culture & Employment & Recreation & Natural Resources & Child Labor \\
\hline Environmental Cost & Efficient Energy & $\begin{array}{l}\text { Freedom of } \\
\text { Association }\end{array}$ & Recruitment & Training \\
\hline Environmental Damage & Renewable Energy & Clean & Reforestation & Leakage \\
\hline
\end{tabular}

After quantification of the words and expressions sought in the firms' Annual Financial Statements, the social and environmental disclosure index (ISOCENV) was calculated as the ratio between the number of words and total expressions and the number of pages of the document, according to Equation 1.

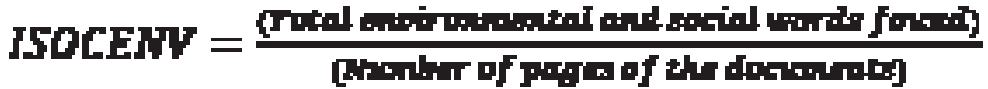

Based on previous studies (Caixe $\&$ Krauter, 2013; Crisostomo \& Pinheiro, 2016; Crisostomo \& Freire, 2015; Li et al., 2015; Farooq \& Zaroauli, 2016), ownership concentration is considered as an independent variable, proxied by the proportion of voting shares in the hands of the main, the two main, and the three main voting shareholders, estimating one model for each of these ownership concentration variables.

To have better fitted models and, therefore, more robust estimates, other variables suggested in the literature as being able to interfere in the level of social and environmental disclosure are introduced in the econometric model: firm membership of an environmentally risky industry; firm membership of the B3 Corporate Sustainability Index (ISE); firm profitability; and firm size.

The econometric model proposed in this paper to examine the hypothesis concerning the effects of the voting ownership concentration on social and environmental disclosure is represented by Equation 2, which also includes the variables mentioned in section 2 : 
$\operatorname{ISOCENV}_{\mathrm{i}, \mathrm{t}}=\beta_{0}+\beta_{1} \mathrm{OWN}_{\mathrm{i}, \mathrm{t}}+\beta_{2} \mathrm{D}_{-} 10165_{\mathrm{i}, \mathrm{t}}+\beta_{3} \mathrm{D}_{-} \mathrm{ISE}_{\mathrm{i}, \mathrm{t}}+\beta_{4} \mathrm{ROA}_{\mathrm{i}, \mathrm{t}}+\beta_{5} \operatorname{SIZE}_{\mathrm{i}, \mathrm{t}}+\varepsilon$

In equation 2, ISOCENV is the social and environmental disclosure index, which is calculated as the ratio between the total number of words and expressions found and the number of pages of the document. OWN is the ownership concentration, estimating the model for the ownership concentration in the hands of the main shareholder (OWN1), for the ownership concentration in the hands of the two main shareholders (OWN2), and for the ownership concentration in the hands of the three main shareholders (OWN3). D_10165 is a dummy variable that presents the value 1 if the firm is from an environmentally risky industry and 0 otherwise, according to Law No. 10,165/2000. This sectoral identification is made as in Law No. 10,165/2000, which classifies the sectors of economic activity according to their potential to damage the environment. D_ISE is a dummy variable that has a value of 1 if firm $i$ is part of the theoretical portfolio of the B3 Corporate Sustainability Index (ISE) in year $t$, and 0 otherwise. ROA is the firm's return-on-assets. SIZE is the firm's size, proxied by the natural logarithm of total assets. $\varepsilon$ is the error.

Descriptive statistics were used to analyze the model variables. Tests for the comparison of means of social and environmental disclosure allowed the comparison between groups of firms. Parametric and non-parametric tests were used in order to give more robustness to the analyses. Models were estimated by ordinary least squares with robust coefficients and standard errors to heteroscedasticity. We also performed tests for multicollinearity by calculating the variance inflation factors (VIFs) for the independent variables of each model. With VIF values between 1 and 10 there is no problem of multicollinearity (Bejar, Mukherjee, \& Moore, 2011; Deshmukh, Goel, \& Howe, 2013).

\section{Empirical Findings}

Table 4 presents descriptive statistics of the model variables. As can be observed, there is a high voting ownership concentration, with the largest shareholder (OWN1) holding, on average, $44.19 \%$ of the firms' common shares. This proportion rises to $63.18 \%$ when considering the three largest shareholders (OWN3). These results are in line with previous ones that detected the high voting ownership concentration of Brazilian firms (Crisóstomo \& Freire, 2015; Caixe \& Krauter, 2013; Okimura et al., 2007). It is also possible to verify a high dispersion of profitability (ROA), with a coefficient of variation of approximately 10.49 .

Table 4

\section{Descriptive statistics}

\begin{tabular}{lccccccc}
\hline Variable & $\mathbf{N}$ & Mean & Deviation & CV & Median & Minimum & Maximum \\
\hline ISOCENV & 1,252 & 0.1266 & 0.1334 & 1.0534 & 0.0835 & 0.0000 & 1.0118 \\
OWN1 & 1,252 & 0.4419 & 0.2610 & 0.5907 & 0.3694 & 1.0000 & 0.0014 \\
OWN2 & 1,252 & 0.5691 & 0.2483 & 0.4363 & 0.5504 & 1.0000 & 0.0014 \\
OWN3 & 1,252 & 0.6318 & 0.2350 & 0.3719 & 0.6268 & 1.0000 & 0.0014 \\
ROA & 1,252 & 0.0157 & 0.1644 & 10.4919 & 0.0305 & 0.9309 & -1.9474 \\
SIZE & 1,252 & 13.6132 & 2.2992 & 0.1689 & 13.8602 & 20.1488 & 2.9444 \\
\hline
\end{tabular}

Note. ISOCENV = social and environmental disclosure. OWN = sum of voting capital in the hands of the 1 st, the two largest, and the three largest shareholders. ROA = return on assets. SIZE = natural logarithm of total assets. 
Table 5 shows the parametric (Student $t$ ) and non-parametric (Mann Whitney $u$ ) tests for the difference in means for distinct firm attributes between firms that are ISE members and non-ISE members, as well as for firms from environmentally risky industries and others, according to the Brazilian Environmental Policy.

Table 5

Parametric and non-parametric tests for the difference in means between groups of firms

\begin{tabular}{lcccccccc}
\hline & \multicolumn{2}{c}{ ISE Firms } & \multicolumn{3}{c}{ Firms from environmental impact industries according to } \\
Law No. 10,165/ 2000
\end{tabular}

Note. ISOCENV = social and environmental disclosure. OWN = sum of voting capital in the hands of the 1 st, the two largest, and the three largest shareholders. $\mathrm{ROA}=$ return on assets. SIZE = natural logarithm of total assets.

It can be observed that the firms listed in the ISE index do in fact present a higher social and environmental disclosure index (ISOCENV) than the others. The results are robust to parametric and non-parametric tests. The same is true for firms from environmentally risky industries, which present higher levels of social and environmental information disclosure in their financial reports when compared to firms considered as not potentially polluting. In this way, the results presented here are in accordance with previous studies carried out on the subject (Rover, \& Santos, 2014; Silva, 2016; Viana Junior \& Crisóstomo, 2016), allowing the suggestion that ISE firms and the ones from environmentally risky industries present a greater concern about social and environmental disclosure.

It should be noted that the ISE firms showed, on average, higher profitability than the others (Table 5). Previous work has shown that ISE requirements are also based on economic and financial aspects, and not only on an environmental basis, which requires the firms listed in this theoretical portfolio to have higher levels of economic performance (Crisóstomo \& Oliveira, 2016; Rufino et al., 2014).

Table 6 presents the correlation analysis of the model variables. There is a positive and significant correlation between social and environmental disclosure (ISOCENV) and the three proxies for ownership concentration (OWN1, OWN2, and OWN3). Thus, it seems that firms with a higher ownership concentration have, in fact, higher levels of social and environmental disclosure, as proposed by the research hypothesis, and also according to previous research results (Diez et al. 2012; Huafang \& Jianguo, 2007). 
Table 6

Correlation matrix of the model variables

\begin{tabular}{|c|c|c|c|c|c|c|}
\hline & ISOCENV & OWN1 & OWN2 & OWN3 & ROA & TAM \\
\hline \multirow[t]{2}{*}{ ISOCENV } & 1.0000 & & & & & \\
\hline & - & & & & & \\
\hline \multirow[t]{2}{*}{ OWN1 } & 0.0672 & 1.0000 & & & & \\
\hline & $(0.0173)$ & - & & & & \\
\hline \multirow[t]{2}{*}{ OWN2 } & 0.0702 & 0.9319 & 1.0000 & & & \\
\hline & $(0.0130)$ & $(0.0000)$ & - & & & \\
\hline \multirow[t]{2}{*}{ OWN3 } & 0.0517 & 0.8663 & 0.9738 & 1.0000 & & \\
\hline & $(0.0676)$ & $(0.0000)$ & $(0.0000)$ & - & & \\
\hline \multirow[t]{2}{*}{ ROA } & 0.0680 & -0.0898 & -0.0879 & -0.1028 & 1.0000 & \\
\hline & $(0.0161)$ & $(0.0015)$ & $(0.0019)$ & $(0.0003)$ & - & \\
\hline \multirow[t]{2}{*}{ SIZE } & 0.1422 & -0.2102 & -0.2394 & -0.2547 & 0.2602 & 1.0000 \\
\hline & $(0.0000)$ & $(0.0000)$ & $(0.0000)$ & $(0.0000)$ & $(0.0000)$ & - \\
\hline
\end{tabular}

Note. ISOCENV = social and environmental disclosure. OWN = sum of voting capital in the hands of the 1 st, the two largest, and the three largest shareholders. ROA = return on assets. SIZE = natural logarithm of total assets. Correlation coefficients and p-values (in parentheses) are displayed.

Table 7 presents the estimates of the social and environmental disclosure models (ISOCENV). As suggested, the voting ownership concentration positively affects the level of firm social and environmental disclosure. The results are consistent in the models estimated with different measures for ownership concentration, involving the sum of the voting shares in the hands of the three main shareholders (OWN1, OWN2, and OWN3). These results support the proposed hypothesis that controlling shareholders of Brazilian firms seem to consider the issue of social and environmental disclosure to be relevant, thus accepting the hypothesis that, in fact, higher firm ownership concentration favors the disclosure of social and environmental actions. This higher attention to the disclosure of information about firm social and environmental actions by controlling shareholders contributes to the reduction of information asymmetry between the firm and market as well as between controlling and minority shareholders. By promoting a reduction of information asymmetry through better disclosure, the firm contributes to minimizing agency conflicts and the resulting costs. At the same time, through the process of more widespread disclosure, the firm may also be motivated by the search for a better image and reputation, as well as the legitimacy of its activities. In the case of high levels of ownership concentration, this concern about reputation may be associated with the interest of the controlling shareholders, which in turn may be contributing to this more intense social and environmental disclosure. 
Table 7

Estimation of Social and Environmental Disclosure Models

\begin{tabular}{|c|c|c|c|}
\hline Variables & (i) & (ii) & (iii) \\
\hline \multirow[t]{2}{*}{ OWN1 } & $0.0361^{* * *}$ & & \\
\hline & $(0.014)$ & & \\
\hline \multirow[t]{2}{*}{ OWN2 } & & $0.0339^{* *}$ & \\
\hline & & $(0.015)$ & \\
\hline \multirow[t]{2}{*}{ OWN3 } & & & $0.0267^{*}$ \\
\hline & & & $(0.016)$ \\
\hline \multirow[t]{2}{*}{ ROA } & $0.0420^{* *}$ & $0.0414^{* *}$ & $0.0413^{* *}$ \\
\hline & $(0.020)$ & $(0.201)$ & $(0.021)$ \\
\hline \multirow[t]{2}{*}{ SIZE } & 0.0010 & 0.0011 & 0.0008 \\
\hline & $(0.002)$ & $(0.002)$ & $(0.002)$ \\
\hline \multirow[t]{2}{*}{ D_10165 } & $0.0228^{*}$ & $0.0234^{* *}$ & $0.0242^{* *}$ \\
\hline & $(0.012)$ & $(0.012)$ & $(0.012)$ \\
\hline \multirow[t]{2}{*}{ D_ISE } & $0.0570^{* * *}$ & $0.0569^{* * *}$ & $0.0564^{* * *}$ \\
\hline & $(0.012)$ & $(0.012)$ & $(0.012)$ \\
\hline \multirow[t]{2}{*}{ constant } & $0.0576^{* *}$ & $0.0539^{*}$ & $0.0589^{* *}$ \\
\hline & $(0.027)$ & $(0.029)$ & $(0.029)$ \\
\hline $\mathrm{N}$ & 1,252 & 1,252 & 1,252 \\
\hline $\mathrm{F}(18,1233)$ & 17.68 & 17.61 & 17.60 \\
\hline Prob > F & 0.0000 & 0.0000 & 0.0000 \\
\hline $\mathrm{R}^{2}$ & 0.2267 & 0.2258 & 0.2244 \\
\hline Root MSE & 0.1181 & 0.1182 & 0.1183 \\
\hline Mean VIF & 1.92 & 1.93 & 1.93 \\
\hline
\end{tabular}

Note. The dependent variable is social and environmental disclosure (ISOCENV). OWN = sum of voting capital in the hands of the 1 st, the two largest, and the three largest shareholders. ROA = return on assets. SIZE = natural logarithm of total assets. D_10165 = 1 for firms classified as potentially polluting industries, 0 otherwise. D_ISE = 1 for firms listed in the ISE, 0 otherwise. Industries and year dummy variables are shown in the models and are not displayed to save space. Models estimated by Ordinary Least Squares (OLS). Estimated coefficients and standard deviations, in parentheses, estimated robust to heteroscedasticity (model of Equation 2). Values of Variance Inflation Factors (VIFs) of all independent variables greater than 1 and less than 10 , indicating absence of multicollinearity problem. ${ }^{* * *},{ }^{* *}$, and ${ }^{*}$ denote the statistical significance of the coefficients at $1 \%, 5 \%$, and $10 \%$, respectively.

The results presented on the positive influence of ownership concentration on the social and environmental disclosure of the Brazilian firms are in line with the findings of studies carried out in other countries, such as Spain and China (Diez et al., 2012; Huafang \& Jianguo, 2007). On the other hand, the findings are different from research results in other countries, such as Kenya, Singapore, and Malaysia (Barako et al., 2006; Eng \& Mark, 2003; Razak \& Mustapha, 2013). The legal system of countries may be a factor contributing to this difference since this second group of countries is characterized by the Common Law legal system, unlike Brazil and the other two countries mentioned, which have a system more aligned with the Civil Law style.

These findings indicate that controlling shareholders would have a propensity to have a more extensive social and environmental policy and to disclose more information about these actions on a voluntary basis. This higher degree of disclosure may be in order to legitimize the firm's actions, as suggested by Legitimacy Theory, and gain reputation for the firm, whose 
image is associated with that of controlling shareholders, who also gain from better firm prestige (Bebbington, Larrinaga-González, \& Moneva-Abadía, 2008; Crisóstomo \& Freire, 2015; Deephouse \& Carter, 2005). In this context, it is worth mentioning the probable longterm perspective of controlling shareholders with respect to the firm, a factor that contributes to the search for better firm reputation and image, which is important in the long run. Under the Agency Theory framework, the power of controlling shareholders can explain this search for legitimacy and gains in corporate image, usually in the medium and long term, even at the expense of short-term benefits, which are more associated with managerial interests (agents) and minority shareholders.

It is also important to mention the positive influence of firm membership of the ISE portfolio (D_ISE) on the degree of social and environmental disclosure, as was expected. ISE firms could in fact be presenting a higher degree of accountability to their stakeholders, which has a positive impact on the degree of social and environmental disclosure. This result is in agreement with previous research in Brazil (Crisóstomo \& Oliveira, 2016; Rover \& Santos, 2014; Rufino et al., 2014; Silva, 2016). Firms that make up the ISE theoretical portfolio would, in fact, be more sensitive to the pressures of the various firm stakeholders in the direction of higher social and environmental commitment, as proposed by the Stakeholder Theory (Freeman \& Phillips, 2002). Such pressures would lead firms to have a high level of information disclosure about social and environmental actions as a way to better meet stakeholders' demands.

Also, as expected, firms from environmentally risky industries (D_10165) present a higher degree of social and environmental disclosure. Such firms, perhaps because of the strong regulations and government control over their activities, may be increasing their social and environmental disclosure as a way to legitimize their actions and signal their high concern about social and environmental aspects, as pointed out by
Legitimacy Theory. It may also be considered that there is a possible regulatory effect (enforcement) of the National Environmental Policy, as the literature has suggested (Feldman, \& Perez, 2009; Pedersen, 2013; Viana Junior \& Crisóstomo, 2017). The Stakeholder approach advocates that stakeholder pressure may be able to make firms more aware of social and environmental issues. This stakeholder pressure can be put directly on the business agent as well as on regulatory agencies that can effectively create legal norms that require firms to have more environmentally responsible conduct. From this perspective, this result in relation to firms with greater potential for causing environmental damage responds positively to the proposition presented by the Stakeholder Theory.

The results also show that the profitability of Brazilian firms seems to be able to boost the degree of social and environmental disclosure, as suggested by the literature (Baron, Harjoto, \& Jo, 2009; Kansal et al., 2014; Marquezan et al., 2015; Zhang, 2015) and signaling a possible financial slack of Brazilian firms, which allows them to pay better attention to their social and environmental performance. On the other hand, the results indicate a lack of effect of firm size on social and environmental disclosure, contrary to expectations and the findings obtained in previous studies that found a positive relationship between firm size and the degree of social and environmental disclosure, assuming that large firms gain economies of scale, suggesting that they have more capacity to publish information at a lower cost (Abdullah et al., 2015; Correa et al., 2017). There is also the argument in defense of the fact that the motivations that lead firms to undertake social and environmental action do not differ between larger and smaller firms (Baumann-Pauly et al., 2013; Udayasankar, 2008). This suggestion that there is no difference in motivation may have an effect on the disclosure of social and environmental information through the mandatory Annual Financial Statements. Larger firms may be investing in a higher degree of disclosure in specific sustainability reports that have more visibility. 


\section{Conclusion}

This study investigated the effect of voting ownership concentration on the social and environmental disclosure of Brazilian firms. The results indicate that firms with higher degrees of voting ownership concentration are more likely to voluntarily disclose social and environmental information. In addition, firms that participate in the Corporate Sustainability Index and ones from environmentally risky industries, as classified by the National Environmental Policy (Law No. $10,165 / 2000)$, present a higher degree of social and environmental disclosure than others.

The results point to the fact that a higher ownership concentration contributes to a higher degree of disclosure of social and environmental information in the financial reports of Brazilian firms, supporting the suggestion that large shareholders are committed to disclosure as a way to legitimize their activities, as Legitimacy Theory proposes, and thus obtain gains in firm reputation, whose image is closely associated with that of controlling shareholders, who directly benefit from positive firm visibility. Under the Agency Theory approach, conflicts of interest can also be identified since controlling shareholders with a lot of power may be, to a certain extent, emphasizing this demand for legitimacy and gains in firm image, usually obtained in the medium and long term, even though this process may adversely affect short-term benefits of managers (agents) and minority shareholders, who will not always benefit from these uncertain long-term gains.

Regarding the superior disclosure of social and environmental information by the firms that compose the theoretical ISE sustainability index, this reality may reflect the demanding selection process for the firms that compose this portfolio. The firms present in the ISE would have a higher level of social and environmental disclosure, reflecting a higher responsibility toward its set of stakeholders. Firms that pass ISE screening would therefore be more sensitive to the pressures of the various stakeholders and have a greater social and environmental concern, as advocated by the Stakeholder approach. This higher concern would be conveyed through social and environmental disclosure.

Firms classified by the Brazilian Environmental Policy (PBMA) as operating in sectors that are more potentially aggressive toward the natural environment seem to have a higher degree of social and environmental disclosure. This finding can be explained from the standpoint of the Stakeholder approach, since stakeholders can encourage firms to have better social and environmental behavior, as well as regulatory bodies to improve norms in order to coerce firms in this sense. Enhancement of environmental laws may also lead to a possible enforcement effect that may also be a factor in explaining this outcome. At the same time, firms from environmentally risky industries may be disclosing more about their social and environmental policies as a way to gain legitimacy in the eyes of society and thus obtain an improvement in prestige among their stakeholders, as foreseen by Legitimacy Theory.

The results of this research suggest that, in fact, there are attributes of Brazilian firms that interfere in their degree of voluntary social and environmental disclosure. This is supported by different theoretical approaches. Thus, it is believed that the work contributes to the literature in some important points. The paper uses a social and environmental disclosure index based on lexical analysis of mandatory accounting reports. This operation is relatively new in Brazil and the use of mandatory reports avoids the bias of voluntary disclosure present in sustainability reports that are optional and carried out by firms that are investing more strongly in this disclosure. In addition, the long period of analysis (20102014) should be mentioned in comparison to previous works in Brazil, as well as the reduction of the subjectivisms of the analysis based on specific terms established in the literature. Finally, the research points out firm attributes that are still scarcely taken into account in the literature as being capable of interfering in the 
degree of voluntary social and environmental disclosure, such as ownership concentration, firm membership of the ISE sustainability index, and whether the firm operates in an industry with more potential to damage the natural environment.

As mentioned, this paper adds contributions to the academic research by using a social and environmental disclosure index based on lexical analysis of mandatory accounting reports over a long period of five years in Brazil. In addition, the work also provides interesting results to the market. The findings indicate that higher ownership concentration is associated with a higher level of social and environmental disclosure, which may be a sign that shareholders with a large proportion of shares are more attentive to such disclosure due to its benefits. The results also indicate a higher level of disclosure included in the Corporate Sustainability Index (ISE), indicating that firms' efforts to be a member of the ISE index seem to be accompanied by more disclosure of social and environmental action. Firms in sectors classified as more potentially harmful to the environment also tend to have a higher degree of social and environmental disclosure, which may be the result of more pressure on such firms with regard to environmental responsibility, where disclosure is a way that they find to be accountable to society.

As a continuation of this work, we envisage the use of other reports to measure the level of disclosure, as well as taking into account additional factors as possible motivators of social and environmental disclosure. Studies with this theme also seem promising since there are sectors with peculiar characteristics that can boost the degree of disclosure of this type of information.

\section{Acknowledgment}

We gratefully acknowledge financial support by Fundação para a Ciência e a Tecnologia, grant UID/GES/00315/2019.

\section{References}

Abdullah, W. A. W., Percy, M., \& Stewart, J. (2015). Determinants of voluntary corporate governance disclosure: evidence from Islamic banks in the Southeast Asian and the Gulf Cooperation Council regions. Journal of Contemporary Accounting \& Economics, 11(3), 262-279.

Abhayawansa, S. \& Guthrie, J. (2012). Intellectual capital information and stock recommendations: impression management? Journal of Intellectual Capital, 13(3), 398-415.

Albertini, E. (2013). Does environmental management improve financial performance? A meta-analytical review. Organization \& Environment, 26(4), 431-457.

Al Jifri, K., \& Citron, D. (2009). The valuerelevance of financial statement recognition versus note disclosure: Evidence from goodwill accounting. European Accounting Review, 18(1), 123-140.

Almeida, T. A., Santos, L. M. F., Cabral, A. C. A., Santos, S. M., \& Pessoa, M. N. M. (2016). Estrutura de propriedade e disclosure econômico e socioambiental nas maiores empresas do Brasil. Revista de Educação e Pesquisa em Contabilidade, 9(4), 362-379.

Alotaibi, K. O. (2016). Determinants and consequences of CSR disclosure quantity and quality: evidence from Saudi Arabia. Doctoral Thesis in Accounting at Plymouth University. Plymouth, UK. Available from <https://pearl. plymouth.ac.uk/bitstream/handle/10026.1/5332 /2016Alotaibi10416096PhDd..pdf?sequence $=1>$. Retrieved on January $18^{\text {th }} 2017$.

Ball, R., Kothari, S. P., \& Robin, A. (2000). The Effect of Institutional Factors on Properties of Accounting Earnings: International Evidence. Journal of Accounting \& Economics, 29(1), 1-52.

Barako, D. G., Hancock, P., \& Izan, H. Y. (2006). Factors influencing voluntary corporate disclosure 
by Kenyan companies. Corporate Governance: An International Review, 14(2), 107-125.

Barnea, A., \& Rubin, A. (2010). Corporate Social Responsibility as a Conflict Between Shareholders. Journal of Business Ethics, 97(1), 71-86.

Baron, David P., Harjoto, Maretno Agus, \& Jo, Hoje. (2011). The Economics and Politics of Corporate Social Performance. Business and Politics, 13(2), 1-46.

Barth, M. E., Cahan, S. F., Chen, L., \& Venter, E. R. (2016). The economic consequences associated with Integrated Report quality: early evidence from a mandatory setting. Available from $<$ https://ssrn.com/abstract=2699409>. Retrieved on July $10^{\text {th }} 2017$.

Batista, A. B., Cruz, N. V. S., \& Bruni, A. L. (2016). Fatores determinantes do nível de divulgação ambiental nas maiores transnacionais brasileiras. Revista Contemporânea de Economia e Gestão, 14(3), 140-161.

Baumann-Pauly, D., Wickert, C., Spence, L. J., \& Scherer, A. G. (2013). Organizing corporate social responsibility in small and large firms: size matters. Journal of Business Ethics, 115(4), 693-705.

Bebbington, J., Larrinaga-González, C., \& Moneva-Abadía, J. M. (2008). Legitimating reputation/the reputation of legitimacy theory. Accounting, Auditing \& Accountability Journal, 21(3), 371-374.

Bejar, S., Mukherjee, B., \& Moore, W. H. (2011). Time horizons matter: the hazard rate of coalition governments and the size of government. Economics of Governance, 12(3), 201-235.

Bouten, L., Everaert, P., Van Liedekerke, L., De Moor, L., \& Christiaens, J. (2011, September). Corporate social responsibility reporting: A comprehensive picture? Accounting Forum, 35(3), 187-204.
Brammer, S., \& Pavelin, S. (2004). Building a Good Reputation. European Management Journal, 22(6), 704-713.

Brandão, I. F., \& Crisóstomo, V. L. (2015). Concentração de propriedade e qualidade da governança da empresa brasileira. Revista Brasileira de Finanças, 13(3), 438-438.

Brown, D. L., Guidry, R. P., \& Patten, D. M. (2009). Sustainability reporting and perceptions of corporate reputation: An analysis using fortune. In M. Freedman \& B. Jaggi (Eds.), Sustainability, Environmental Performance and Disclosures (Vol. 4, pp. 83-104): Emerald Group Publishing Limited.

Bruton, G. D., Filatotchev, I., Chahine, S., \& Wright, M. (2010). Governance, ownership structure, and performance of IPO firms: The impact of different types of private equity investors and institutional environments. Strategic Management Journal, 31(5), 491-509.

Burgwal, D. V., \& Vieira, R. J. O. (2014). Environmental disclosure determinants in Dutch listed companies. Revista Contabilidade e Finanças, 25(64), 60-78.

Caixe, D. F., \& Krauter, E. (2013). A influência da estrutura de propriedade e controle sobre o valor de mercado corporativo no Brasil. Revista Contabilidade \& Finanças, 24(62), 142-153.

Cardoso, V. I. C., De Luca, M. M. M., \& Gallon, A. V. (2014). Reputação corporativa e o disclosure socioambiental de empresas brasileiras. Contabilidade, Gestâo e Governança, 17(2), 26-35.

Carroll, A. B., \& Shabana, K. M. (2010). The Business Case for Corporate Social Responsibility: A Review of Concepts, Research and Practice. International Journal of Management Reviews, 12(1), 85-105.

Correa, J. C., Gonçalves, M. N., Sanches, S. L. R., \& de Oliveira Moraes, R. (2018). Disclosure socioambiental de empresas Norte-Americanas 
listadas na NYSE: características e os possíveis fatores para a divulgação voluntária. Contabilidade Vista \& Revista, 28(2), 53-77.

Costa, B. M. N., \& Crisóstomo, V. L. (2017). Comprehensiveness of Corporate Social Responsibility Reports of Brazilian Companies: An Analysis of its Evolution and Determinants. Cuadernos de Contabilidad, 18(45), 125-151.

Crisóstomo, V. L., \& Pinheiro, B. G. (2015). Estrutura de capital e concentração de propriedade da empresa brasileira. Revista de Finanças Aplicadas, 4(1), 1-30.

Crisóstomo, V. L., \& Oliveira, M. R. (2016). Uma Análise dos Determinantes da Responsabilidade Social das Empresas Brasileiras. Brazilian Business Review, 13(4), 75-97.

Crisóstomo, V. L., Souza, J. L., \& Parente, P. H. N. (2012). Possível efeito regulatório na responsabilidade socioambiental da empresa brasileira em função da Lei $n^{\circ} 10.165 / 2000$. Revista de Gestão Social e Ambiental, 6(3), $157-$ 170.

Crisóstomo, V. L., \& Freire, F. S. (2015). The influence of ownership concentration on firm resource allocations to employee relations, external social actions, and environmental action. Review of Business Management, 17(55), 987-1006.

Cullinan, C. P., Wang, F., Wang, P., \& Zhang, J. (2012). Ownership structure and accounting conservatism in China. Journal of International Accounting, Auditing and Taxation, 21(1), 1-16.

Deephouse, D. L., \& Carter, S. M. (2005). An Examination of Differences Between Organizational Legitimacy and Organizational Reputation. Journal of Management Studies, 42(2), 329-360.

Delmas, M., Hoffmann, V. H., \& Kuss, M. (2011). Under the tip of the iceberg: Absorptive capacity, environmental strategy, and competitive advantage. Business \& Society, 5O(1), 116-154.
Deshmukh, S., Goel, A. M., \& Howe, K. M. (2013). CEO overconfidence and dividend policy. Journal of Financial Intermediation, 22(3), 440-463.

Dhaliwal, D. S., Li, O. Z., Tsang, A., \& Yang, Y. G. (2011). Voluntary nonfinancial disclosure and the cost of equity capital: The initiation of corporate social responsibility reporting. The Accounting Review, 86(1), 59-100.

Diez, J. L. G., Gago, R. F., \& Garcia, L. C. (2012). Propriedad y control en la práctica de la RSC. Cuadernos de Economía y Dirección de la Empresa, 15(1), 1-11.

Djankov, S., La Porta, R., Lopez-de-Silanes, F., \& Shleifer, A. (2008). The law and economics of self-dealing. Journal of Financial Economics, 88(3), 430-465.

Domenico, D. D., Magro, C. B. D., Mazzioni, S., Preis, M. B., \& Klann, R. C. (2015). Determinantes do nível de disclosure nos relatórios de sustentabilidade em conformidade com o Global Reporting Initiative. Revista Gestão \& Sustentabilidade Ambiental, 4(2), 4-30.

Eisenhardt, K. M. (1989). Agency Theory: An Assessment and Review. The Academy of Management Review, 14(1), 57-74.

Eng, L. L., \& Mak, Y. T. (2003). Corporate governance and voluntary disclosure. Journal of Accounting and Public Policy, 22(4), 325-345.

Epstein, M. J. (2003). The identification, measurement, and reporting of corporate social impacts: Past, present, and future. Advances in Environmental Accounting \& Management, 2(1), 1-29.

Esa, E., Zahari, A. R. (2016). Corporate social responsibility: ownership structures, board characteristics and the mediating role of board compensation. Procedia Economics and Finance, 35(1), 35-43. 
Faller, C. M., \& Knyphausen, D. A. (2016). Does equity ownership matter for corporate social responsibility? A literature review of Theories and recent empirical findings. Journal of Business Ethics, 1-26

Fama, E. F., \& Jensen, M. C. (1983). Separation of Ownership and Control. Journal of Law and Economics, 26(2), 301-325.

Farooq, O., \& Zarouali, I. (2016). Financial centers and ownership concentration: When is ownership concentration value relevant? Evidence from an emerging market. Research in International Business and Finance, 38(3), 236-245.

Feldman, Yuval, \& Perez, Oren. (2009). How Law Changes the Environmental Mind: An Experimental Study of the Effect of Legal Norms on Moral Perceptions and Civic Enforcement. Journal of Law and Society, 36(4), 501-535.

Fernandes, S. M. (2013). Fatores que influenciam o disclosure ambiental: um estudo nas empresas brasileiras no período de 2006 a 2010. Revista Ambiente Contábil, 5(2), 250-267.

Frankel, R., \& Li, X. (2004). Characteristics of a firm's information environment and the information asymmetry between insiders and outsiders. Journal of Accounting and Economics, 37(2), 229-259.

Freeman, R. E., \& Phillips, R. A. (2002). Stakeholder Theory: a libertarian defense. Business Ethics Quarterly, 12(3), 331-349.

Gamerschlag, R., Möller, K., \& Verbeeten, F. (2011). Determinants of voluntary CSR disclosure: empirical evidence from Germany. Review of Managerial Science, 5(2-3), 233-262.

Ghazali, N. A. M. (2007). Ownership structure and corporate social responsibility disclosure: some Malaysian evidence. Corporate Governance: The International Journal of Business in Society, 7(3), 251-266.
Gray, R., Javad, M., Power, D. M., \& Sinclair, C. D. (2001). Social and environmental disclosure and corporate characteristics: A research note and extension. Journal of Business finance \& accounting, 28(3), 327-356.

Griffin, Jennifer J., \& Mahon, John F. (1997). The corporate social performance and corporate financial performance debate: Twenty-five years of incomparable research. Business and Society Review, 36(1), 5-31.

Guedhami, O., \& Pittman, J. A. (2006). Ownership concentration in privatized firms: The role of disclosure standards, auditor choice, and auditing infrastructure. Journal of Accounting Research, 44(5), 889-929.

Hand, J. R. (2005). The value relevance of financial statements in the venture capital market. The Accounting Review, 80(2), 613-648.

Hendriksen, E. S.; Van Breda, M. F. (1999). Teoria da contabilidade. São Paulo: Atlas.

Hitt, M. A., Ireland, R. D., \& Hoskisson, R. (2008). Administração estratégica. 2. ed. São Paulo: Cengage Learning.

Huafang, X., \& Jianguo, Y. (2007). Ownership structure, board composition and corporate voluntary disclosure: Evidence from listed companies in China. Managerial Auditing Journal, 22(6), 604-619.

Huang, A. H., Zang, A. Y., \& Zheng, R. (2014). Evidence on the Information Content of Text in Analyst Reports. The Accounting Review, 89(6), 2151-2180.

Jensen, M. C., \& Meckling, W. H. (1976). Theory of Firm: Managerial Behavior, agency costs and capital structure. Journal of Financial Economics, 3(4), 11-25.

Kansal, M., Joshi, M., \& Batra, G. S. (2014). Determinants of corporate social responsibility 
disclosures: Evidence from India. Advances in Accounting, 30(1), 217-229.

Kolk, A., Walhain, S., \& Van de Wateringen, S. (2001). Environmental reporting by the Fortune Global 250: exploring the influence of nationality and sector. Business Strategy and the Environment, 1O(1), 15-28.

La Porta, R., Lopez-de-Silanes, F., Shleifer, A., \& Vishny, R. (2000). Investor protection and corporate governance. Journal of Financial Economics, 58(1), 3-27.

Legendre, S., \& Coderre, F. (2013). Determinants of GRI G3 Application Levels: The Case of the Fortune Global 500. Corporate Social Responsibility and Environmental Management, 20(3), 182-192.

Lei n. 10.165, de 27 de dezembro de 2000 (2000). Altera a Lei no 6.938, de 31 de agosto de 1981, que dispóe sobre a Política Nacional do Meio Ambiente, seus fins e mecanismos de formulação e aplicação, e dá outras providências.

Li, W., \& Zhang, R. (2010). Corporate social responsibility, ownership structure, and political interference: Evidence from China. Journal of Business Ethics, 96, 631-645.

Lin, C.-P., \& Chuang, C.-M. (2011). PrincipalPrincipal Conflicts and IPO Pricing in an Emerging Economy. Corporate Governance: An International Review, 19(6), 585-600.

Madeira, F. L., \& Costa Junior, J. V. (2015). Value relevance dos outros resultados abrangentes nas companhias abertas brasileiras. Advances in Scientific and Applied Accounting, 8(2), 204-217.

Marquezan, L. H. F., Seibert, R. M., Bartz, D., Barbosa, M. A. G., \& Alves, T. W. (2015). Análise dos determinantes do disclosure verde em relatórios anuais de empresas listadas na BM\&FBovespa. Contabilidade, Gestão e Governança, 18(1), 127-150.
Michelon, G. (2011). Sustainability disclosure and reputation: A comparative study. Corporate Reputation Review, 14(2), 79-96.

Morck, R., Wolfenzon, D., \& Yeung, B. (2005). Corporate Governance, Economic Entrenchment, and Growth. Journal of Economic Literature, 43(3), 655-720.

Naser, K., Al-Hussaini, A., Al-Kwari, D., \& Nuseibeh, R. (2006). Determinants of corporate social disclosure in developing countries: The case of Qatar. Advances in International Accounting, 19(1), 1-23.

Okimura, R. T., Silveira, A. D. M. D., \& Rocha, K. C. (2007). Estrutura de propriedade e desempenho corporativo no Brasil. Revista de Administração Contemporânea, 1(1), 119-135.

Pedersen, Ole W. (2013). Environmental enforcement undertakings and possible implications: responsive, smarter or rent seeking? The Modern Law Review, 76(2), 319-345.

Razak, S. E. A., \& Mustapha, M. (2013). Corporate social responsibility disclosures and board structure: Evidence from Malaysia. Jurnal Teknologi, 64(3), 73-80.

Renders, A., \& Gaeremynck, A. (2012). Corporate Governance, Principal-Principal Agency Conflicts, and Firm Value in European Listed Companies. Corporate Governance: An International Review, 20(2), 125-143.

Rees, W., \& Rodionova, T. (2015). The Influence of Family Ownership on Corporate Social Responsibility: An International Analysis of Publicly Listed Companies. Corporate Governance: An International Review, 23(3), 184-202.

Rover, S., \& Santos, A. (2014). Revisitando os determinantes do disclosure voluntário socioambiental no Brasil: em busca de robustez na mensuração da variável socioambiental. Contabilometria, 1(2), 15-35. 
Rover, S., Tomazzia, E. C., Murcia, F. D., \& Borba, J. A. (2012). Explicaçôes para a divulgação voluntária ambiental no Brasil utilizando a análise de regressão em painel. Revista de Administração, $47(2), 217-230$.

Rufino, M. A., Mazer, L. P., Machado, M. R., \& Cavalcante, P. R. N. (2014). Sustentabilidade e performance dos indicadores de rentabilidade e lucratividade: um estudo comparativo entre os bancos integrantes e não integrantes do ISE da BM\&FBovespa. Revista Ambiente Contábil, 6(1), 1-18.

Said, R., Hj Zainuddin, Y., \& Haron, H. (2009). The relationship between corporate social responsibility disclosure and corporate governance characteristics in Malaysian public listed companies. Social Responsibility Journal, 5(2), 212-226.

Shleifer, A., \& Vishny, R. W. (1997). A Survey of Corporate Governance. Journal of Finance, 52(2), 737-783.

Shleifer, A., \& Wolfenzon, D. (2002). Investor protection and equity markets. Journal of Financial Economics, 66(1), 3-27.

Silva, G. R. (2016). A relação entre disclosure voluntário de ações sustentáveis e gerenciamento de resultados: um estudo empírico nas companhias brasileiras listadas na BM\&FBovespa. Revista de Auditoria, Governança e Contabilidade, 4(16), 108-124.

Silva, M. N., Lima, J. A. S. O., Freitas, M. A. L., Silva Filho, L. L., \& Lagioia, U. C. T. (2015). Determinantes do disclosure ambiental nos relatórios de empresas listadas na Bovespa. Revista Ambiente Contabil, 7(2), 1-15.

Suchman, M. (1995). Managing legitimacy: strategic and institutional approaches. Academy of Management Review, 20(3), 571-601.
Tannuri, G., \& Van Bellen, H. M. (2014). Indicadores de desempenho ambiental evidenciados nos relatórios de sustentabilidade: uma análise à luz de atributos de qualidade. Revista de Gestão Social e Ambiental, 8(1), 2-19.

Udayasankar, K. (2008). Corporate Social Responsibility and Firm Size. Journal of Business Ethics, 83(2), 167-175.

Viana Junior, D. B. C. (2016). Disclosure socioambiental via redes sociais: um estudo nas empresas listadas no Ibrx-100 da BM\&FBovespa. Revista de Gestão Ambiental e Sustentabilidade, 5(2), 19-33.

Viana Junior, D. B. C., \& Crisóstomo, V. L. (2016). Nível de disclosure ambiental das empresas pertencentes aos setores potencialmente agressivos ao meio ambiente. Contabilidade, Gestão e Governança, 19(2), 254-273.

Viana Junior, D. B. C., \& Crisóstomo, V. L. (2017). Nível de disclosure socioambiental: uma análise comparativa entre empresas brasileiras de acordo com o potencial de agressão ao meio ambiente. Revista de Administração da UFSM, 10(Ed. Especial), 79-99.

Wang, J., Song, L., \& Yao, S. (2013). The determinants of corporate social responsibility disclosure: evidence from China. Journal of Applied Business Research, 29(6), 1833-1847.

Wilmshurst, T. D., \& Frost, G. R. (2000). Corporate environmental reporting: A test of legitimacy theory. Accounting, Auditing \& Accountability Journal, 13(1), 10-26.

Young, M. N., Peng, M. W., Ahlstrom, D., Bruton, G. D., \& Jiang, Y. (2008). Corporate Governance in Emerging Economies: A Review of the Principal-Principal Perspective. Journal of Management Studies, 45(1), 196-220.

Zhang, J. (2015). Voluntary information disclosure on social media. Decision Support Systems, 73(3), 28-36. 
Authors:

1. Dante Baiardo Cavalcante Viana Junior, PhD Student in Management, University Institute of Lisbon, Lisbon, Portugal. E-maisl:dantebcviana@gmail.com

ORCID

(iD) 0000-0001-6902-3057

2. Vicente Lima Crisóstomo, PhD in Finance, University of Valladolid, Spain. E-maisl: vlc@ufc.br

ORCID

(iD 0000-0002-8593-0471

\section{Contribution of each author}

\begin{tabular}{lcc}
\hline Contribution & Dante Baiardo & Vicente Lima \\
\hline 1. Definition of research problem & $\sqrt{ }$ & $\sqrt{ }$ \\
2. Development of hypotheses or research questions (empirical studies) & $\sqrt{ }$ & $\sqrt{ }$ \\
3. Development of theoretical propositions (theoretical work) & $\sqrt{ }$ \\
4. Theoretical foundation/ Literature review & $\sqrt{ }$ & $\sqrt{ }$ \\
5. Definition of methodological procedures & $\sqrt{ }$ \\
6. Data collection & $\sqrt{ }$ & $\sqrt{ }$ \\
7. Statistical analysis & $\sqrt{ }$ \\
8. Analysis and interpretation of data & $\sqrt{ }$ \\
9. Critical revision of the manuscript & & $\sqrt{ }$ \\
10. Manuscript writing & & \\
11. Other (please specify which) & & $\sqrt{ }$ \\
\hline
\end{tabular}

\section{Erratum}

Where was written:

“Review of Business Management, São Paulo, v.21, n.5, p.906-927, oct/dec. 2019.”

Now read:

“Rev. Bras. Gest. Neg. São Paulo v.21 n.4 oct-dec. 2019 p. 906-927” 